\title{
Recovery of Residual Brewer's Yeast by Electroactivation
}

\author{
Ruslan Tarna ${ }^{1}$, Elvira Vrabie ${ }^{2}$, Irina Paladii ${ }^{2}$, Rodica Sturza ${ }^{{ }^{*}}$ \\ ${ }^{1}$ Technical University of Moldova, Chisinau, Republic of Moldova \\ ${ }^{2}$ Institute of Applied Physics, Chisinau, Moldova \\ Email: *rodica.sturza@chim.utm.md
}

How to cite this paper: Tarna, R., Vrabie, E., Paladii, I. and Sturza, R. (2021) Recovery of Residual Brewer's Yeast by Electroactivation. Food and Nutrition Sciences, $12,1177-1190$

https://doi.org/10.4236/fns.2021.1212086

Received: November 1, 2021

Accepted: December 5, 2021

Published: December 8, 2021

Copyright (c) 2021 by author(s) and Scientific Research Publishing Inc. This work is licensed under the Creative Commons Attribution International License (CC BY 4.0).

http://creativecommons.org/licenses/by/4.0/

(c) (i) Open Access

\begin{abstract}
Yeasts resulting from the brewing process (RBY) are a valuable by-product, with an important content of minerals, vitamins and, especially, proteins. The purpose of the research was the electroactivation of RBY and the simultaneous obtaining of two products-protein concentrates and hydrolyzed protein from residual brewer's yeast. Electroactivation is a non-residual process, without the use of chemical reagents and relatively inexpensive. The variation of the electroactivation conditions allowed the separation of $90 \%-94 \%$ of the proteins in the form of protein concentrates. During the process, it is attested to increase the $\mathrm{pH}$ value and decrease the redox potential, which characterizes the multiple redox processes that take place in the cathode cell, including sedimentation at the isoelectric point. The presence of albumin in the protein fractions of RBY allows the formation of protein complexes with calcium, attributing a higher biological value to the obtained products.
\end{abstract}

\section{Keywords}

Brewer's Yeast, Electroactivation, Redox Potential, Protein Concentrates, Protein Hydrolysates, Calcium

\section{Introduction}

One of the objectives of the circular economy is the efficient recovery of agroindustrial waste [1]. The coherent application of separation processes for the recovery of value-added compounds, such as bioactive peptides from agro-industrial and biotechnological by-products depends on the development of integrated processes adapted to the specificity of these materials. Brewery residues are a major problem in the brewing business, due to the large volumes generated daily

[2]. The holistic analysis of the exploitation of all residues in the beer industry is 
challenging, and the obtaining of high value-added products requires new approaches to modern treatment processes [3] [4].

Residual beer yeast (RBY) (known as residual yeast or excess yeast) is a predominant by-product of the beer industry, obtained as a residue from fermentation processes in beer production, is no longer useful and requires its elimination. It is estimated to produce between 15 - 18 tons of residual yeast per 10,000 $\mathrm{hL}$ of finished beer and is the second largest by-product in the beer industry [5]. RBY contains significant residual carbohydrates (35\% - 45\% of dry biomass), proteins $(45 \%-60 \%)$, amino acids, minerals, lipids and enzymes, as well as ethanol residues, which require expensive additional separation processing [6]. The chemical composition of RBY according to different sources is shown in Tables 1-3.

$\mathrm{RBY}$ is a protein-rich by-product with a high percentage of essential amino acids [15]. It has been established that about $40 \%$ of the total amino acid content consists of essential amino acids [16]. The use of RBY is also of great interest in the animal feed sector or as a source of bioactive compounds, such as polyphenols and $\beta$-glycans, as substrates for biotechnological applications [16]. The amino acid profiles of the extracts, compared to Saccharomyces cerevisiae and rootlets, another by-product of the beer industry, RBY has a high level of essential amino acids, as shown in Figure 1 [17] [18] [19].

RBY processing encompasses a wide range of methods or a combination of several processes. Enzymatic hydrolysis has been used successfully in the production of peptides and protein hydrolysates from RBY. The hydrolysates obtained require further efficient processing, namely the use of membranes, which is an

Table 1. Chemical composition of residual beer yeast.

\begin{tabular}{|c|c|c|c|c|c|c|}
\hline $\begin{array}{l}\text { Chemical } \\
\text { Composition }\end{array}$ & $\begin{array}{l}\text { Vieira et al. } \\
(2016)[7] \\
\text { (g/100g DM) }\end{array}$ & $\begin{array}{l}\text { Cabellero-Cordoba } \\
\text { and Sgarbieri } \\
(2000)[8],(\%)\end{array}$ & $\begin{array}{l}\text { Saksinchai et al. } \\
\text { (2001) [9], } \\
(\% w / w)\end{array}$ & $\begin{array}{l}\text { Marson et al. } \\
(2020)[10] \\
(\% \mathrm{DM})\end{array}$ & $\begin{array}{l}\text { Mathias et al. } \\
(2015)[11] \\
\text { (\% DM) }\end{array}$ & $\begin{array}{c}\text { Jacob et al. } \\
(2019)[12], \\
(\mathrm{g} / 100 \mathrm{~g})\end{array}$ \\
\hline Proteins & $64.1 \pm 0.2$ & 47.19 & n.d. & 40,8 & 45,6 & $74.3 \pm 0.5$ \\
\hline$\alpha$-amino nitrogen & $12.9 \pm 0.1$ & n.d. & $4.5 \pm 0.2$ & n.d. & $4.09 \pm 0.04$ & $5.81 \pm 0.10$ \\
\hline Ash & $14.0 \pm 0.2$ & 8.55 & $13.3 \pm 0.7$ & $7.0 \pm 0.1$ & $5.9 \pm 0.05$ & $13.5 \pm 2.3$ \\
\hline Lipids & $1.32 \pm 0.04$ & 3.53 & n.d. & 0,21 & n.d. & $0.67 \pm 0.01$ \\
\hline Humidity & $7.70 \pm 0.12$ & n.d. & n.d. & n.d. & n.d. & 6.8 \\
\hline Carbohydrates & $12.9 \pm 0.1$ & 21.52 & $26.8 \pm 0.3$ & n.d. & n.d. & 14.7 \\
\hline RNA & $4.00 \pm 0.16$ & 7.04 & $\begin{array}{c}21.3 \pm 0.4 \\
\text { (with orcinol) } \\
23.2 \pm 0.6 \\
(\mathrm{UV}, 260 \mathrm{~nm})\end{array}$ & $1.9 \pm 0.1$ & n.d. & $5.518 \pm 0.105$ \\
\hline Soluble fiber & n.d. & 9.65 & n.d. & $6.6 \pm 0.1$ & n.d. & n.d. \\
\hline Insoluble fiber & n.d. & 2.57 & n.d. & & n.d. & n.d. \\
\hline
\end{tabular}

N.d.: Not determined; DM: Dry Matter. 
Table 2. Mineral composition of residual beer yeast extract and recommended dietary allowance.

\begin{tabular}{|c|c|c|c|}
\hline Elements & $\begin{array}{l}\text { Vieira et al. (2016) } \\
\text { [7], mg/100g DM }\end{array}$ & $\begin{array}{l}\text { Jacob et al. (2019) } \\
{[12], \mathrm{mg} / 100 \mathrm{~g} \text { DM }}\end{array}$ & $\begin{array}{c}\text { RDA (FSAI) } \\
{[13]}\end{array}$ \\
\hline \multicolumn{4}{|l|}{ Macro elements } \\
\hline Sodium $(\mathrm{Na})$ & $1228 \pm 22$ & $88.1 \pm 0.001$ & $1600 \mathrm{mg}$ \\
\hline Potassium (K) & $9148 \pm 69$ & $6248.7 \pm 21$ & $2000 \mathrm{mg}$ \\
\hline Calcium $(\mathrm{Ca})$ & $27.1 \pm 0.40$ & $16.4 \pm 0.1$ & $800 \mathrm{mg}$ \\
\hline Magnesium (Mg) & $273 \pm 2$ & $210.2 \pm 3.1$ & $375 \mathrm{mg}$ \\
\hline \multicolumn{4}{|l|}{ Oligo elements } \\
\hline Chrome (Cr) & $0.019 \pm 0.00$ & n.d. & $40 \mu \mathrm{g}$ \\
\hline Iron $(\mathrm{Fe})$ & $1.76 \pm 0.03$ & $3.672 \pm 0.010$ & $14 \mathrm{mg}$ \\
\hline Manganese (Mn) & $0.564 \pm 0.013$ & $0.15 \pm 0.01$ & $2 \mathrm{mg}$ \\
\hline Cobalt (Co) & $0.030 \pm 0.001$ & $0.252 \pm 0.010$ & n.a \\
\hline Molybdenum (Mo) & $0.003 \pm .001$ & n.d. & $50 \mu \mathrm{g}$ \\
\hline Zinc $(\mathrm{Zn})$ & $11.9 \pm 0.29$ & $9.963 \pm 0.031$ & $10 \mathrm{mg}$ \\
\hline Copper $(\mathrm{Cu})$ & $0.364 \pm 0.001$ & $0.221 \pm 0.011$ & $1 \mathrm{mg}$ \\
\hline Selenium (Se) & $0.030 \pm 0.00$ & n.d. & $55 \mu \mathrm{g}$ \\
\hline
\end{tabular}

N.d.: Not determined; DM: Dry Matter; RDA: Recommended Dietary Allowance; N.a.: Not allocated.

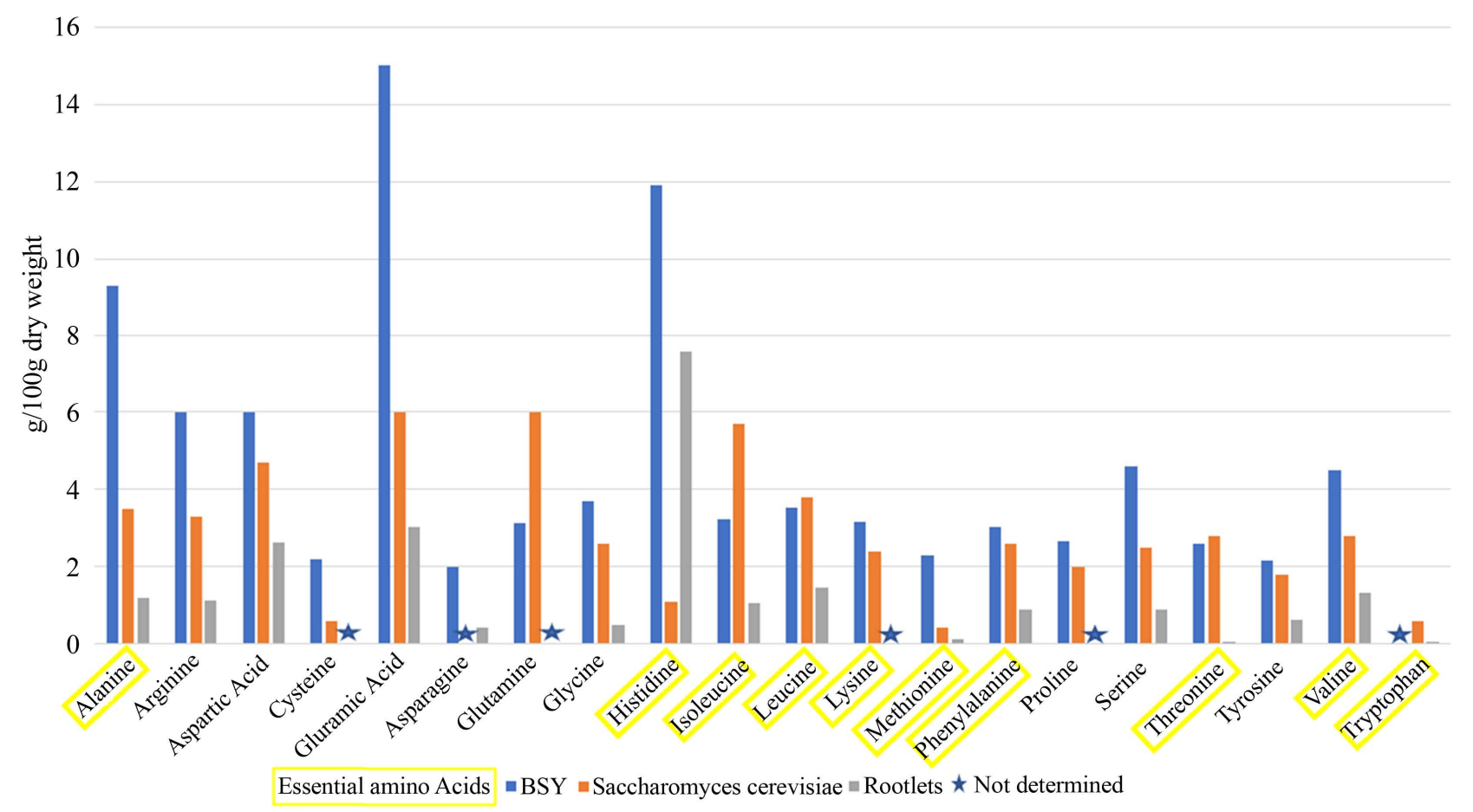

Figure 1. RBY amino acid profiles compared to Saccharomyces cerevisiae and rootlets (essential amino acids are inserted in yellow) [17] [18] [19]. 
Table 3. Vitamin content of residual beer yeast extract and recommended dietary allowance.

\begin{tabular}{|c|c|c|c|c|}
\hline Vitamins & $\begin{array}{l}\text { Vieira et al. } \\
(2016),[7] \\
\text { mg/100g DM }\end{array}$ & $\begin{array}{l}\text { Jacob et al. } \\
\text { (2019), [12], } \\
\text { mg/100g DM }\end{array}$ & $\begin{array}{l}\text { Pinto et al. } \\
\text { (2013), [14], } \\
\text { mg/100g DM }\end{array}$ & $\begin{array}{c}\text { RDA } \\
\text { (FSAI), } \\
{[13]}\end{array}$ \\
\hline Thiamine & n.q. & $7.46 \pm 0.5$ & n.q. & $1.1 \mathrm{mg}$ \\
\hline Nicotinic Acid (B3) & $77.2 \pm 1.1$ & $78.6 \pm 2.0$ & $0.79 \pm 0.06$ & $16 \mathrm{mg}$ \\
\hline Pyridoxine (B6) & $55.1 \pm 2.5$ & $5.90 \pm 0.5$ & $9.99 \pm 0.06$ & $1.4 \mathrm{mg}$ \\
\hline Folic Acid (B9) & $3.01 \pm 0.02$ & $5.29 \pm 0.1$ & $0.25 \pm 0.03$ & $200 \mu \mathrm{g}$ \\
\hline Riboflavin (B2) & n.q. (0.329) & $10.6 \pm 0.5$ & $2.34 \pm 0.03$ & $1.4 \mathrm{mg}$ \\
\hline Cyanocobalamin (B12) & n.q $(0.256)$ & $0.16 \pm 0.1$ & n.q. & $2.5 \mu \mathrm{g}$ \\
\hline
\end{tabular}

DM: Dry matter; RDA: Recommended dietary allowance; N.q.: Not quantified.

important tool for recovering thermolabile and sensitive compounds from complex mixtures, with low energy consumption and high specificity.

The integration of techniques with the use of membranes allows the separation by different filtering mechanisms and those based on the difference in load are of great interest for improving the purity of the extracted fractions. Separation processes with the use of membranes offer several advantages: easy operating conditions without state changes, low energy consumption, compared to conventional concentration processes, high selectivity, wide range of applications, modular design, simplicity in continuous operation and integration. It usually offers a high yield associated with very good purity of the product, thus allowing an efficient approach to wastewater treatment, as well as the recovery of several valuable components of by-products [20] [21] [22] [23].

Extraction of peptides in protein hydrolysates from RBY is of particular interest in non-residual processing. The properties of peptides and proteins depend on their profile and structure. Thus, their separation from mixtures with complex composition must be achieved by light methods (low temperatures and neutral $\mathrm{pH}$ values) with high selectivity, in order to maintain the structural and physico-chemical characteristics of the molecules [24] [25] [26]. Separation performance is determined by membrane selectivity and permeate flow, which are dependent on operating conditions (temperature, pressure, process configuration, module characteristics, cleaning procedure), membrane properties (membrane material and structure, pore size) and feed characteristics ( $\mathrm{pH}$, concentration, composition and physico-chemical characteristics) [27]. The objective of selective separation is also an important aspect of the design of the fractionation process [20].

In the context of protein hydrolysate extraction, membrane processes have the ability to maintain protein stability throughout the process and allow for highefficiency separation, which is possible at low temperatures. They do not require the use of solvents and other chemicals [28]. Several biotechnological and phar- 
maceutical applications rely on these advantages to obtain high quality fractions [29]. RBY has a high value of chemical oxygen use (COD) of $0.53 \mathrm{~kg} / \mathrm{hL}$, it cannot be eliminated in wastewater streams without prior treatment, which has a severe negative effect on the environment [30].

Separation technologies with the application of membranes are used successfully and can be considered an integral part of the continuous processing of agro-industrial, food, pharmaceutical and biotechnological products [31]. RBY treatment processes require productive technologies that are efficient and robust enough to explain the intrinsic variability and sometimes fluctuating availability of by-products throughout the year [32] [33] [34].

Extraction of peptides from RBY requires several steps of chemical or mechanical transformation of the cell wall and proteolytic hydrolysis to ensure the transformation of proteins into peptides [35]. The resulting yeast extract contains several macro and micronutrients that must be separated correctly before applying them as new ingredients. Thus, having a more purified product, with higher protein content and fewer unwanted secondary substances, the hydrolysate requires further processing. The separation and fractionation of yeast proteins can be performed by chromatographic methods that have high selectivity, but very high operating costs [36] [37] [38].

The potential of reuse and transformation of this material has been addressed by several authors in an attempt to reduce environmental impact of beer production and promote the recovery of a nutrient-rich by-product [37] [38] [39]. Electroactivation of biological media has a non-residual process, without the use of chemical reagents and relatively inexpensive, which allows the fractionation and obtaining of high quality products [40].

The aim of the research was to simultaneously obtain two products-protein concentrates from residual brewer's yeast (PCRBY) and hydrolyzed protein from residual brewer's yeast (HPRBY) by the electroactivation method.

\section{Materials and Methods}

The fresh residual brewer's yeast was collected at JSC "VITANTA", Chisinau, Moldova. PCRBY and HPRBY were extracted from RBY upon electroactivation with the EDP-0.5 electrolyzer, which has the ratio of the processed volume to the surface of the electrode, $\mathrm{V} / \mathrm{S}=5 \mathrm{ml} / \mathrm{cm}^{2}$ (Figure 2). The electroactivation was performed at different processing regimes-the density of the electric current $j=$ $20 \mathrm{~mA} / \mathrm{cm}^{2}$, remaining constant during the processing, stationary regime of cutting the working liquid (RBY) in the cathode cell (CC) and the secondary liquid ( $2 \% \mathrm{CaCl}_{2}$ solution) in the anode cell (CA). Cationic heterogeneous membrane MK-40 was used [40].

The protein content $(\mathrm{Q}, \%)$ was determined by the Warburg method [41]. The Warburg spectrophotometric method allows the quantitative determination of proteins by the property of aromatic amino acids (tyrosine, tryptophan and phenylalanine) to absorb ultraviolet light at the wavelength $\lambda=278 \mathrm{~nm}$. The 


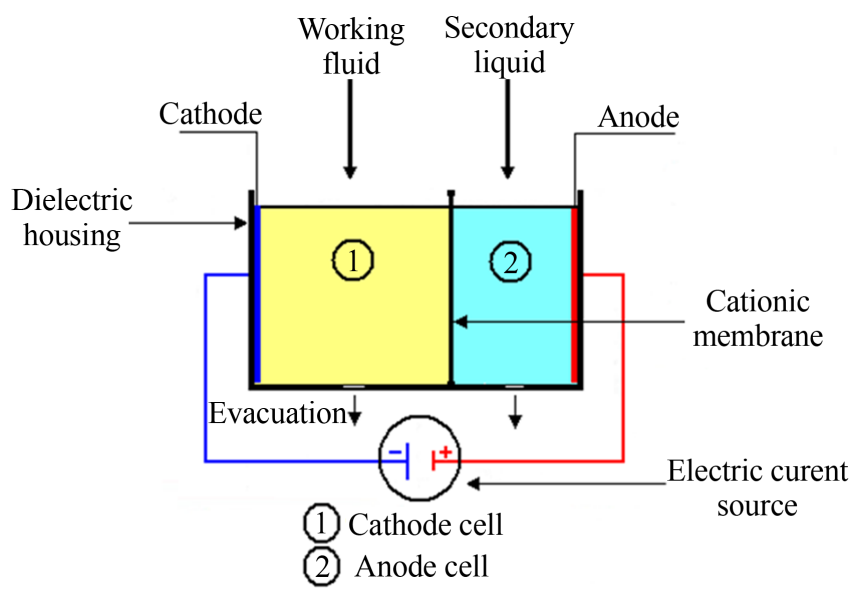

Figure 2. Scheme of the EDP-0.5 diaphragm electrolyzer.

mass concentration of proteins depending on the content of aromatic amino acids has a different absorption range of ultraviolet waves. Conventionally, it is considered that at an average protein concentration in solution, equal to 1 $\mathrm{mg} / \mathrm{ml}$, the optical density is equal to 1.0 at the wavelength $\lambda=278 \mathrm{~nm}$, at the thickness of the liquid layer equal to $1 \mathrm{~cm}$.

Collection of the mixture of PCRBY and HPRBY were performed every 5 minutes as a foam, then separation of the fractions of PCRBY and HPRBY by subsequent centrifugation $(1500 \mathrm{G})$ in the following configurations:

- Configuration 1-undiluted RBY processing; electric current density $j=20$ $\mathrm{mA} / \mathrm{cm}^{2}$.

- Configuration 2-diluted RBY processing (dilution 1:3); $j=20 \mathrm{~mA} / \mathrm{cm}^{2}$.

- Configuration 3-diluted RBY processing (dilution 1:5); $j=20 \mathrm{~mA} / \mathrm{cm}^{2}$.

All tests were performed in triplicate. Results were expressed as mean \pm standard deviation (SD) and were statistically evaluated $(\mathrm{p}<0.05)$.

\section{Results and Discussion}

Undiluted RBY electroactivation, according to configuration 1, allowed the extraction of protein fractions in PCRBY of approximately $93 \%$ - 94\% in the first 5 - $10 \mathrm{~min}$ of processing. Towards the end of the process (20 - $25 \mathrm{~min})$ there was an increase in the protein content (HPRBY, approximately 10\%) (Figure 3).

The protein profile of RBY consists of low molecular weight proteins (caseins, albumin), which are subjected to hydrolysis and form peptide-rich hydrolysates.

The variation of $\mathrm{pH}$ values and redox potential $(\mathrm{E}, \mathrm{mV})$ at undiluted $\mathrm{RBY}$ electroactivation characterizes the multiple redox processes that take place in the cathode cell, including sedimentation at the isoelectric point (pI) (Figure 4).

The processing of undiluted RBY was difficult, conditioned by the formation of several active complexes, which tend to migrate through the membrane, which led to its intense soaking, confirmed by the rapid increase in voltage.

Dilution of RBY (1:3) allowed more intense hydrolysis of protein content and extraction of about 16\% protein in HPRBY (Figure 5). 


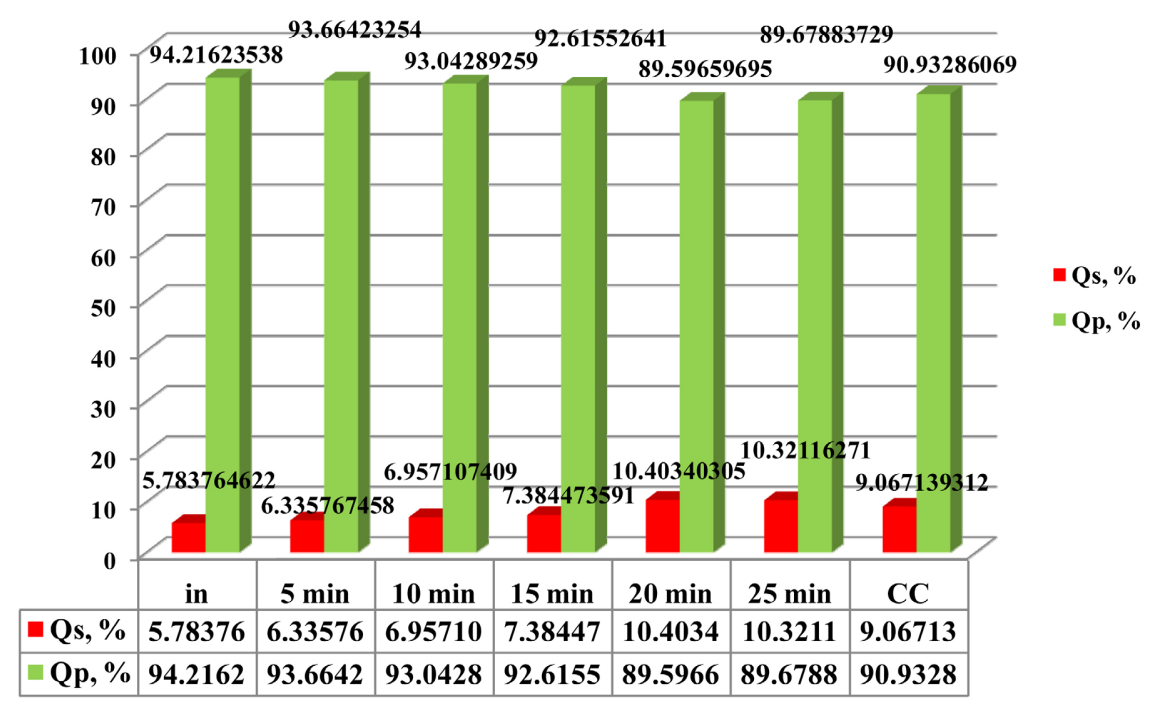

Figure 3. Variation of protein content at undiluted RBY electroactivation. $j=20 \mathrm{~mA} / \mathrm{cm}^{2}$ (C1); protein content in PCRBY (Qp, \%) and HPRBY (Qs, \%).
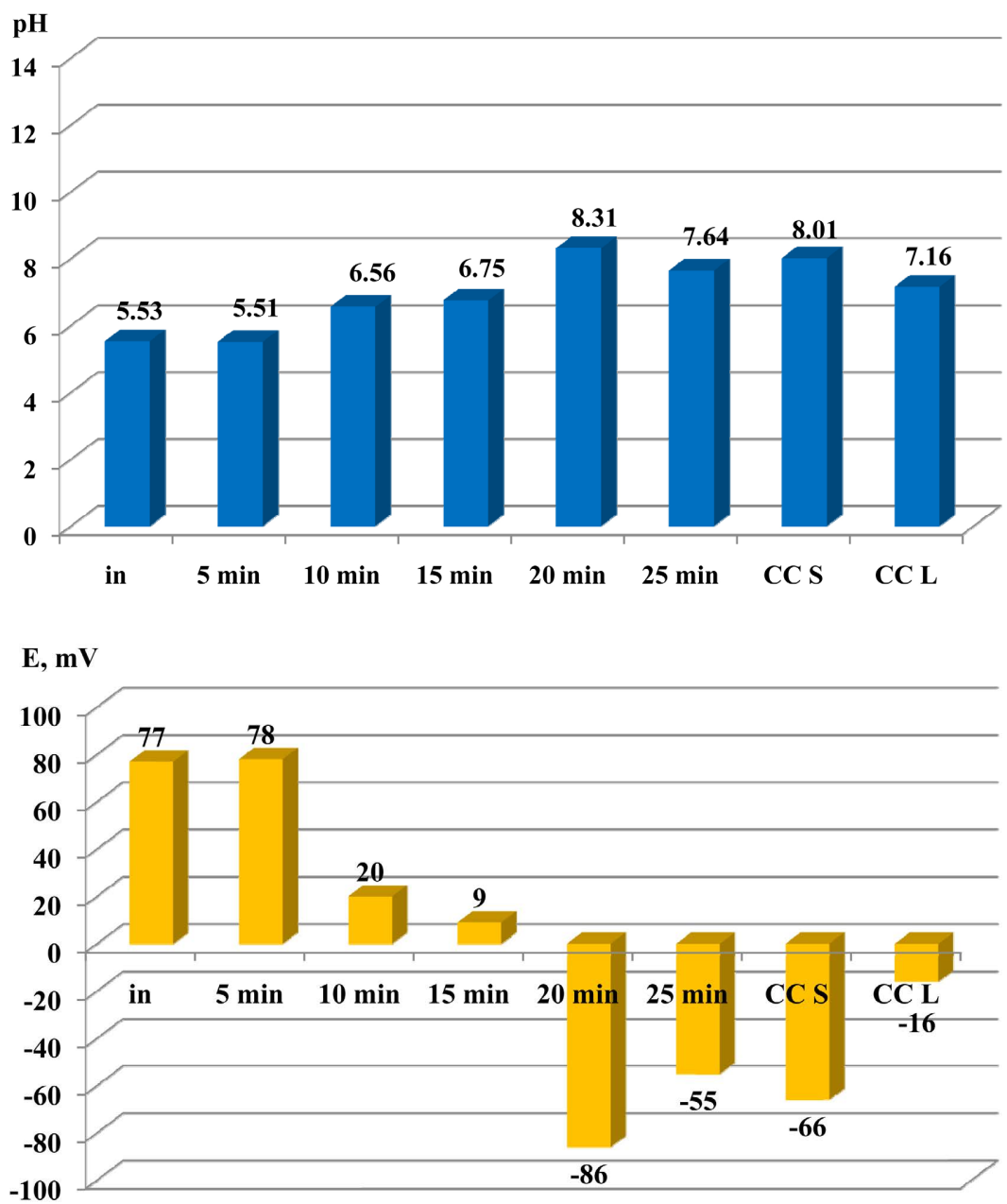

Figure 4. Variation of $\mathrm{pH}$ values and redox potential $(\mathrm{E}, \mathrm{mV})$ when electroactivating undiluted RBY (C1). $j=20 \mathrm{~mA} / \mathrm{cm}^{2}$; CC S-Cathode cell content (foam phase); CC LCathode cell content (liquid phase). 


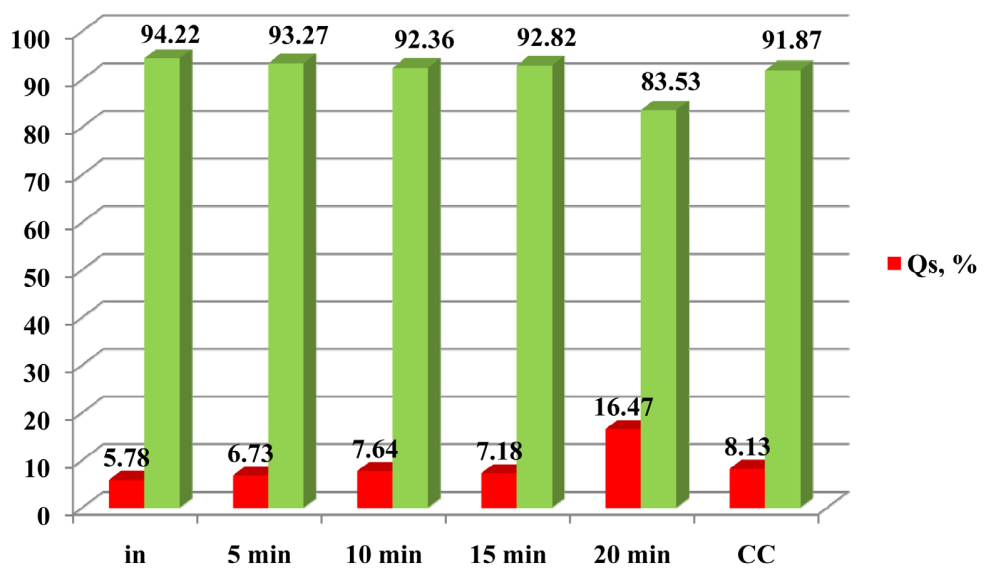

Figure 5. Variation of protein content upon electroactivation of diluted RBY (1:3). $j=20$ $\mathrm{mA} / \mathrm{cm}^{2}(\mathrm{C} 1)$; protein content: PCRBY (Qp, \%) and HPRBY (Qs, \%).

The faster increase of the $\mathrm{pH}$ values and, respectively, the decrease of the redox potential values are an obvious indication of the multiple processes that take place at the electroactivation of diluted RBY, confirming the intensification of the dilution process by increasing the activation surface (Figure 6). The low values of the redox potential highlight the reduction reactions, which lead to the hydrolysis of proteins and, respectively, the obtaining of hydrolysates.

Diluted (1:5) RBY electroactivation (configuration 3) allowed more intense hydrolysis of proteins, thus obtaining in the liquid phase a mixture of protein hydrolysates almost three times larger for the end of processing in the liquid phase of CC (Figure 7).

The $\mathrm{pH}$ values towards the end of the process are intensely alkaline, creating favorable conditions for obtaining protein hydrolysates from RBY. Negative values of redox potential (E, $\mathrm{mV}$ ) at $15-20 \mathrm{~min}$ of processing (C3), confirm the reduction reactions to diluted RBY electroactivation. This can be explained by increasing the activation area (Figure 8).

The obtained results demonstrate that the electroactivation of RBY allows obtaining two fractions: protein concentrates and protein hydrolysates. Multiple mechanisms require confirmation by supplementation by electrophoretic research of protein concentrates from residual brewer's yeast (PCRBY) and hydrolyzed protein from residual brewer's yeast (HPRBY).

The intense flow of calcium ions through heterogeneous MK-40 membranes in the anode cell allows the ennobling of protein concentrates and hydrolysates with these ions. The presence of albumin in the protein fractions of RBY allows the formation of protein complexes with calcium, attributing a higher biological value to the obtained products.

The presence of caseins in RBY most likely leads to the aggregation of protein compounds by the formation of the calcium-phosphate caseinate complex. Calcium caseinate is formed at the interaction of calcium ions with the carboxyl and phosphoserine groups of casein. In this case calcium reacts with two groups $-\mathrm{COOH}$ and $-\mathrm{OH}-$ at short distances, forming intermolecular calcium bridges: 

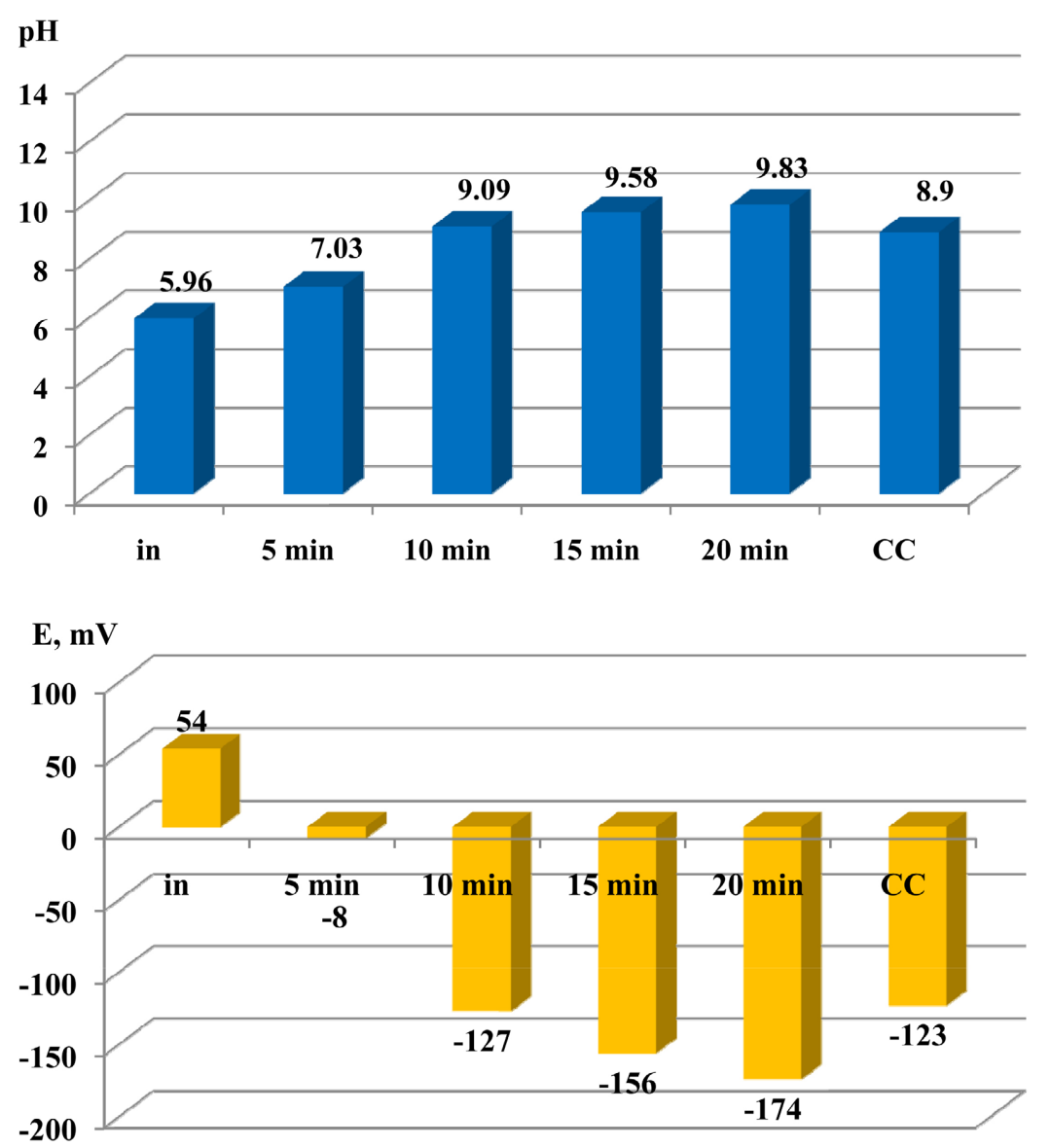

Figure 6. Variation of $\mathrm{pH}$ and redox potential $(\mathrm{E}, \mathrm{mV})$ values at 1:3 diluted $\mathrm{RBY}$ electroactivation (C2). $j=20 \mathrm{~mA} / \mathrm{cm} \mathrm{2}$; CC S-Cathode cell content (foam phase); CC LCathode cell content (liquid phase).

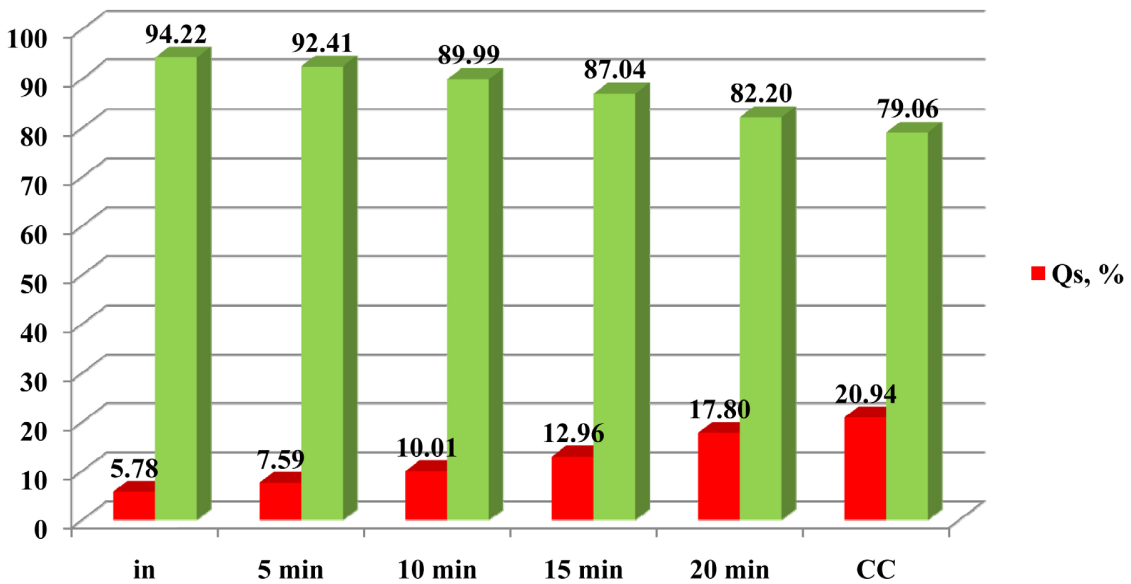

Figure 7. Variation of protein content upon electroactivation of diluted RBY (1:5). $j=20$ $\mathrm{mA} / \mathrm{cm}^{2}$ (C3); protein content: PCRBY (Qp, \%) and HPRBY (Qs, \%).

-R-Ca-R-. It is assumed that hydrophosphate ions may also participate in the formation of structural bridges, between two phosphoserine groups: - $\mathrm{R}-\mathrm{Ca}-\mathrm{HPO}_{4}{ }^{-}$ $\mathrm{Ca}-\mathrm{R}$ - or -R-Ca- $\mathrm{HPO}_{4}$-Ca- $\mathrm{HPO}_{4}$-Ca-R-. 

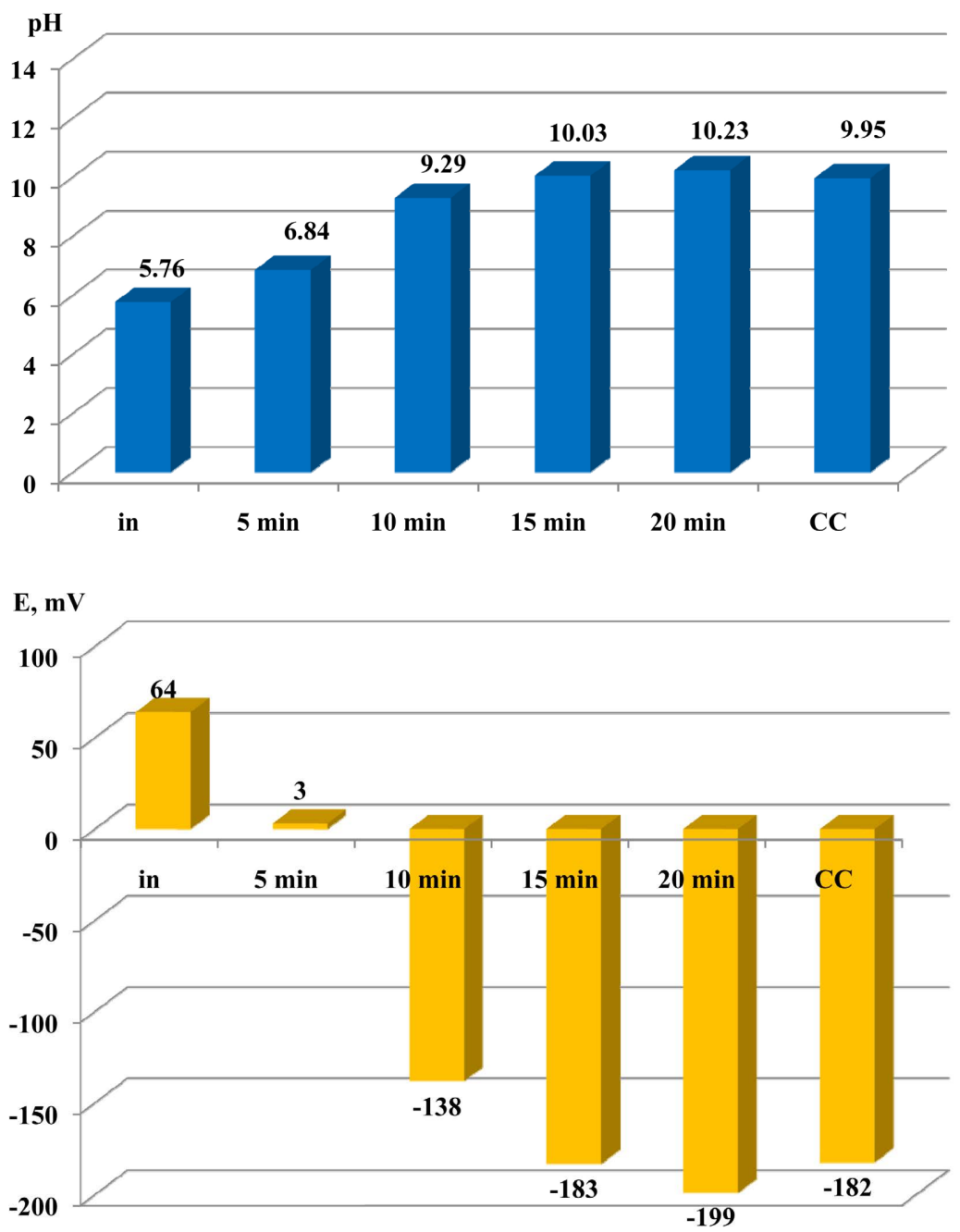

Figure 8. Variation of $\mathrm{pH}$ and redox potential $(\mathrm{E}, \mathrm{mV})$ values at 1:5 diluted $\mathrm{RBY}$ electroactivation (C3). $j=20 \mathrm{~mA} / \mathrm{cm}^{2}$.

\section{Conclusions}

RBY electroactivation allowed the separation of fractions and the obtaining of protein concentrates and protein hydrolysates. In the fractionation of peptides and proteins, the effects associated with electroactivation and processing parameters were taken into account, which allowed the recovery of economically viable peptides. The integration of load-based separation techniques as well as the elucidation of the underlying separation mechanisms can improve the efficiency of bioseparations.

Several possibilities involve the recovery of value-added compounds from RBY. The production of fractions with a high content of peptides, but with a low content of polysaccharides and fibers is a great challenge.

Preventive dilution of RBY allowed to increase the activation surface and quantitatively intensified the obtaining of protein hydrolysates. The flow of calcium ions through the heterogeneous membrane ennobles the products obtained by electroactivation with these ions. 
Recovery of different fractions enriched in different high value-added components, such as peptides for different applications, oligosaccharides, minerals and amino acids is possible through multiple fractionation processes. This can increase the economic viability of the RBY processing.

\section{Acknowledgements}

The research was funded in the framework of State Project 21.00208.8007.07/PD: Recovery of waste from the Beer Industry. The authors would like to thank the Project 2SOFT/1.2/83 "Intelligent valorization of agro-food industrial wastes (INTELWASTES)", funded by the European Union, within the program Cross border cooperation Romania-Republic of Moldova 2014-2020.

\section{Conflicts of Interest}

The authors declare no conflicts of interest regarding the publication of this paper.

\section{References}

[1] Birikorang, S., Connor, G., Pullammanappallil, P. and Mohan, G. (2013) Recovery of Essential Plant Nutrients from Biofuel Residual. Journal of Sustainable Bioenergy Systems, 3, 149-159. https://doi.org/10.4236/jsbs.2013.32021

[2] Flores-Copa, V., Romero-Soto, L., Romero-Calle, D.X., Alvarez-Aliaga, M.T., OrozcoGutierrez, F., Vega-Baudrit, J.R., Martín, C. and Carrasco, C. (2021) Residual Brewing Yeast as Substrate for Co-Production of Cell Biomass and Biofilm Using Candida Maltosa SM4. Fermentation, 7, 84. https://doi.org/10.3390/fermentation7020084

[3] González-García, S., Morales, P.C. and Gullón, B. (2018) Estimating the Environmental Impacts of a Brewery Waste-Based Biorefinery: Bio-Ethanol and Xylooligosaccharides Joint Production Case Study. Industrial Crops and Products, 123, 331-340. https://doi.org/10.1016/j.indcrop.2018.07.003

[4] Mathias, T.R.S., Mello, P.P.M. and Sérvulo, E.F.C. (2014) Solid Wastes in Brewing Process: A Review. Journal of Brewing and Distilling, 5, 1-9. https://doi.org/10.5897/JBD2014.0043

[5] Byerlee, D. and Fanzo, J. (2019) The SDG of Zero Hunger 75 Years on: Turning Full Circle on Agriculture and Nutrition. Global Food Security, 21, 52-59.

https://doi.org/10.1016/j.gfs.2019.06.002

[6] Jaeger, A., Arendt, E.K., Zannini, E. and Sahin, A.W. (2020) Brewer's Spent Yeast (BSY), an Underutilized Brewing By-Product. Fermentation, 6, 123.

https://doi.org/10.3390/fermentation6040123

[7] Vieira, E.F., Moura, C., Almeida, T.C., Meireles, S., Brandão, T., Pinho, O. and Ferreira, I.M. (2012) Influence of Serial Repitching on Beer Polypeptide Profiles. Journal of the American Society of Brewing Chemists, 70, 275-279. https://doi.org/10.1094/ASBCJ-2012-0918-01

[8] Vieira, E.F., Carvalho, J.S., Pinto, E., Cunha, S.C., Almeida, A.A. and Ferreira, I.M. (2016) Nutritive Value, Antioxidant Activity and Phenolic Compounds Profile of Brewer's Spent Yeast Extract. Journal of Food Composition and Analysis, 52, 44-51. https://doi.org/10.1016/j.jfca.2016.07.006 
[9] Caballero-Córdoba, G.M. and Sgarbieri, V.C. (2000) Nutritional and Toxicological Evaluation of Yeast (Saccharomyces cerevisiae) Biomass and a Yeast Protein Concentrate. Journal of the Science of Food and Agriculture, 80, 341-351. https://doi.org/10.1002/1097-0010(200002)80:3<341::AID-JSFA533>3.0.CO;2-M

[10] Saksinchai, S., Suphantharika, M. and Verduyn, C. (2001) Application of a Simple Yeast Extract from Spent Brewer's Yeast for Growth and Sporulation of Bacillus thuringiensis subsp. kurstaki: A Physiological Study. World Journal of Microbiology and Biotechnology, 17, 307-316. https://doi.org/10.1023/A:1016717428583

[11] Marson, G.V., Saturno, R.P., Comunian, T.A., Consoli, L., Machado, M. and Hubinger, M.D. (2020) Maillard Conjugates from Spent Brewer's Yeast BY-product as an Innovative Encapsulating Material. Food Research International (Ottawa, Ont.), 136, Article ID: 109365. https://doi.org/10.1016/j.foodres.2020.109365

[12] Mathias, T.R., Fernandes de Aguiar, P., Batista de Almeida E Silva, J., Moretzsohn de Mello, P.P. and Sérvulo, E.F. (2017) Brewery Waste Reuse for Protease Production by Lactic Acid Fermentation. Food Technology and Biotechnology, 55, 218-224. https://doi.org/10.17113/ftb.55.02.17.4378

[13] Jacob, F.F., Michel, M., Zarnkow, M., Hutzler, M. and Methner, F.-J. (2019) The Complexity of Yeast Extracts and Its Consequences on the Utility in Brewing: A Review. Brewing Science, 72, 50-62.

[14] Commission Directive (2008) 2008/100/EC of 28 October 2008 Amending Council Directive 90/496/EEC on Nutrition Labelling for Foodstuffs as Regards Recommended Daily Allowances, Energy Conversion Factors and Definitions. Official Journal of the European Union, 51, 1-4.

[15] Pinto, M., Coelho, E., Nunes, A., Brandão, T. and Coimbra, M.A. (2015) Valuation of Brewers Spent Yeast Polysaccharides: A Structural Characterization Approach. Carbohydrate Polymers, 116, 215-222. https://doi.org/10.1016/j.carbpol.2014.03.010

[16] Alu'datt, M.H., Ereifej, K.I., Abu-Zaiton, A.S., Alrababah, M.A., Almajwal, A.M., Rababah, T.M. and Yang, W. (2012) Anti-Oxidant, Anti-Diabetic, and Anti-Hypertensive Effects of Extracted Phenolics and Hydrolyzed Peptides from Barley Protein Fractions. International Journal of Food Properties, 15, 781-795. https://doi.org/10.1080/10942912.2010.503357

[17] Jacob, F., Hutzler, M. and Methner, F. (2018) Comparison of Various Industrially Applicable Disruption Methods to Produce Yeast Extract Using Spent Yeast from Top-Fermenting Beer Production: Influence on Amino Acid and Protein Content. European Food Research and Technology, 245, 95-109.

https://doi.org/10.1007/s00217-018-3143-Z

[18] Waters, D.M., Kingston, W., Jacob, F., Titze, J.F., Arendt, E.K. and Zannini, E. (2013) Wheat Bread Biofortification with Rootlets, a Malting By-Product. Journal of the Science of Food and Agriculture, 93, 2372-2383.

https://doi.org/10.1002/jsfa.6059

[19] Martini, A.E., Miller, M.W. and Martini, A. (1979) Amino Acid Composition of Whole Cells of Different Yeasts. Journal of Agricultural and Food Chemistry, 27, 982-984. https://doi.org/10.1021/jf60225a040

[20] Castro-Muñoz, R., Barragán-Huerta, B.E., Fíla, V., Denis, P. and Ruby-Figueroa, R. (2018) Current Role of Membrane Technology: From the Treatment of AgroIndustrial By-Products up to the Valorization of Valuable Compounds. Waste and Biomass Valorization, 9, 513-529. https://doi.org/10.1007/s12649-017-0003-1

[21] Saxena, A., Tripathi, B.P., Kumar, M. and Shahi, V.K. (2009) Membrane-Based Techniques for the Separation and Purification of Proteins: An Overview. Advances 
in Colloid and Interface Science, 145, 1-22. https://doi.org/10.1016/j.cis.2008.07.004

[22] van Reis, R. and Zydney, A. (2001) Membrane Separations in Biotechnology. Current Opinion in Biotechnology, 12, 208-211.

https://doi.org/10.1016/S0958-1669(00)00201-9

[23] Jung, E.Y., Lee, H.S., Choi, J.W., Ra, K.S., Kim, M.R. and Suh, H.J. (2011) Glucose Tolerance and Antioxidant Activity of Spent Brewer's Yeast Hydrolysate with a High Content of Cyclo-His-Pro (CHP). Journal of Food Science, 76, C272-C278. https://doi.org/10.1111/j.1750-3841.2010.01997.x

[24] Marson, G.V., Machado, M.T., de Castro, R.J. and Hubinger, M.D. (2019) Sequential Hydrolysis of Spent Brewer's Yeast Improved Its Physico-Chemical Characteristics and Antioxidant Properties: A Strategy to Transform Waste into Added-Value Biomolecules. Process Biochemistry, 84, 91-102.

https://doi.org/10.1016/j.procbio.2019.06.018

[25] Ortiz-Martinez, M., Winkler, R. and García-Lara, S. (2014) Preventive and Therapeutic Potential of Peptides from Cereals against Cancer. Journal of Proteomics, 111, 165-183. https://doi.org/10.1016/j.jprot.2014.03.044

[26] Ambrosi, A., Cardozo, N.S. and Tessaro, I.C. (2014) Membrane Separation Processes for the Beer Industry: A Review and State of the Art. Food and Bioprocess Technology, 7, 921-936. https://doi.org/10.1007/s11947-014-1275-0

[27] Habert, A.C., Borges, C.P. and Nobrega, R. (2006) Aspectos Gerais dos Processos com Membranas. In: Habert, A.C., Borges, C.P. and Nobrega, R., Eds., Processos de Separação por Membranas, E-papers, Rio de Janeiro, 9-24.

[28] Cui, Z., Jiang, Y. and Field, R. (2010) Chapter 1-Fundamentals of Pressure-Driven Membrane Separation Processes. In: Cui, Z. and Muralidhara, H., Eds., Membrane Technology, Butterworth-Heinemann, Oxford, 1-18. https://doi.org/10.1016/B978-1-85617-632-3.00001-X

[29] Etzel, M. and Arunkumar, A. (2016) Chapter 6-Novel Membrane Technologies for Protein Concentration and Fractionation. In: Knoerzer, K., Juliano, P. and Smithers, G., Eds., Innovative Food Processing Technologies, Woodhead Publishing Series in Food Science, Technology and Nutrition; Woodhead Publishing, Cambridge, 151-175. https://doi.org/10.1016/B978-0-08-100294-0.00006-7

[30] Amorim, M., Pereira, J.O., Gomes, D., Pereira, C., Pinheiro, H. and Pintado, M.E. (2016) Nutritional Ingredients from Spent Brewer's Yeast Obtained by Hydrolysis and Selective Membrane Filtration Integrated in a Pilot Process. Journal of Food Engineering, 185, 42-47. https://doi.org/10.1016/j.jfoodeng.2016.03.032

[31] Vollet Marson, G., Belleville, M.P., Lacour, S. and Dupas Hubinger, M. (2020) Membrane Fractionation of Protein Hydrolysates from By-Products: Recovery of Valuable Compounds from Spent Yeasts. Membranes, 11, 23.

https://doi.org/10.3390/membranes11010023

[32] Castro-Muñoz, R., Boczkaj, G., Gontarek, E., Cassano, A. and Fíla, V. (2020) Membrane Technologies Assisting Plant-Based and Agro-Food By-Products Processing: A Comprehensive Review. Trends in Food Science and Technology, 95, 219-232. https://doi.org/10.1016/j.tifs.2019.12.003

[33] Ashraf, A., Ramamurthy, R. and Rene, E.R. (2021) Wastewater Treatment and Resource Recovery Technologies in the Brewery Industry: Current Trends and Emerging Practices. Sustainable Energy Technologies and Assessments, 47, Article ID: 101432. https://doi.org/10.1016/j.seta.2021.101432

[34] Meshksar, M., Roostaee, T. and Rahimpour, M.R. (2020) Membrane Technology for Brewery Wastewater Treatment. In: Current Trends and Future Developments on 
(Bio-) Membranes, Elsevier, Amsterdam, 289-303.

https://doi.org/10.1016/B978-0-12-816823-3.00010-1

[35] Chae, H.J., Joo, H. and In, M.J. (2001) Utilization of Brewer's Yeast Cells for the Production of Food-Grade Yeast Extract. Part 1: Effects of Different Enzymatic Treatments on Solid and Protein Recovery and Flavor Characteristics. Bioresource Technology, 76, 253-258. https://doi.org/10.1016/S0960-8524(00)00102-4

[36] Kanauchi, O., Igarashi, K., Ogata, R., Mitsuyama, K. and Andoh, A. (2005) A Yeast Extract High in Bioactive Peptides Has a Blood-Pressure Lowering Effect in Hypertensive Model. Current Medicinal Chemistry, 12, 3085-3090. https://doi.org/10.2174/092986705774933461

[37] Baczek, T. (2004) Fractionation of Peptides and Identification of Proteins from Saccharomyces cerevisiae in Proteomics with the Use of Reversed-Phase Capillary Liquid Chromatography and pI-Based Approach. Journal of Pharmaceutical and Biomedical Analysis, 35, 895-904. https://doi.org/10.1016/j.jpba.2004.02.032

[38] Ghosh, R. and Cui, Z. (2000) Protein Purification by Ultrafiltration with PreTreated Membrane. Journal of Membrane Science, 167, 47-53.

https://doi.org/10.1016/S0376-7388(99)00275-6

[39] San Martin, D., Orive, M., Iñarra, B., Castelo, J., Estévez, A., Nazzaro, J., Iloro, I., Elortza, F. and Zufía, J. (2020) Brewers' Spent Yeast and Grain Protein Hydrolysates as Second-Generation Feedstuff for Aquaculture Feed. Waste and Biomass Valorization, 11, 1-14. https://doi.org/10.1007/s12649-020-01145-8

[40] Vrabie, E., Bologa, M., Paladii, I., Stepurina, T., Vrabie, V., Goncharuk, V.P., Polikarpov, A.A. and Sprinchan, C.G. (2019) Electrical Processing of Whey. Role of Construction, Technological and Energy Characteristics of Reactors. Surface Engineering and Applied Electrochemistry, 55, 197-209. https://doi.org/10.3103/S1068375519020145

[41] Warburg, O. and Christian, W. (1942) Isolation and Crystallization of Enolase. Biochemische Zeitschrift, 310, 384-421. 